\title{
The importance of adequate anticoagulation to prevent early thrombosis after stenting of stenosed venous bypass grafts
}

\begin{abstract}
Stent implantation in native coronary arteries may be complicated by acute thrombosis, despite the use of stringent anticoagulation. Thrombotic occlusion of stented venous grafts may occur less frequently, possibly because of the larger caliber of these grafts. We report our experience with 46 stents (Wallstent, Medinvent, Lausanne, Switzerland) implanted in 35 lesions of 24 consecutive patients (mean age 64 years, range 43 to 75 ). Two overlapping stents were implanted in seven patients, and three overlapping stents were positioned in two. After implantation, activated partial thromboplastin time was maintained at two to three times the control level by intravenous administration of heparin (160 to $550 \mathrm{mg}$ daily) until thrombotest values were reduced $5 \%$ to $10 \%$ by acenocoumarol. Impending thrombotic occlusion was recognized in two suboptimally anticoagulated patients: patient $A$ after implantation of four stents and patient $B$ after anticoagulation therapy was discontinued because of acute upper gastrointestinal bleeding. Coronary artery bypass grafting was performed successfully in both patients. A third patient had a myocardial infarction on day 7 after stent implantation, in spite of adequate anticoagulation and optimal medical drug therapy. It is concluded that stringent anticoagulation therapy appears mandatory to maintain graft patency after stent implantation. (AM HeART J 1991; 121:1389.)
\end{abstract}

Jeroen J. J. Bucx, MD, Ivan de Scheerder, MD, Kevin Beatt, MD, Marcel van den Brand, MD, Harry Suryapranata, MD, PhD, Pim J. de Feyter, MD, PhD, and Patrick W. Serruys, MD, PhD.

Rotterdam, The Netherlands

Patients with venous bypass grafts are at risk of having atherosclerotic degeneration of the graft. ${ }^{1-3}$ Both short- and long-term results after balloon dilatation of this type of lesion, and notably angioplasty of completely occluded grafts, appear to be less favorable than results in native coronary arteries. ${ }^{4-6}$ In approximately $3 \%$ of patients the procedure may be complicated by peripheral embolization of the bypass atheroma, resulting in peripheral occlusion and myocardial infarction. ${ }^{4} 6$ The restenosis rate in dilated venous bypass grafts is higher than that in native vessels; particularly the proximal anastomosis is prone to restenosis ( $46 \%$ ), the risk is intermediate in the shaft of the vein graft $(35 \%)$ and lowest at the distal anastomosis (24\%). ${ }^{8}$ It has been reported that only $46 \%$ of patients were symptom free 5 years

From the Department of Cardiology, Thoraxcenter, Academic Hospital Dijkzigt, Erasmus University Rotterdam.

Received for publication Sept. 4, 1990; accepted Oct. 17, 1990.

Reprint requests: P. W. Serruys, MD, PhD, Catheterization Laboratory, Thuraxcenter, Erasmus University Rotterdam, PO Box 1738, 3000 Dr, Rotterdam, The Netherlands.

4/1/27812 after angioplasty of a saphenous vein graft compared with $79 \%$ after balloon dilatation of native vessels. ${ }^{9}$

Recently it has been suggested that stent implantation at the dilatation site may improve both shortand long-term results. ${ }^{10,11}$ Evaluation of the use of these devices may be even more appealing in view of the increasing number of patients that have recurrent angina after venous bypass grafting. ${ }^{9}$ The aim of this analysis was to assess the need for anticoagulation therapy to prevent thrombotic complications after successful stent implantation in venous bypass grafts. Obviously the risk of complications inherent in anticoagulation therapy should compare favorably with the possible gain in safety, improved success rate, and better immediate hemodynamic results when these new interventions are applied in a highrisk patient population.

\section{METHODS}

Patients. The patient population consisted of 24 consecutive patients who had previously undergone venous aortocoronary bypass surgery and had recurrent angina pectoris (Canadian Heart Association class III to IV). The 
Table I. Drug treatment before and 3 months after stent implantation

\begin{tabular}{lcc}
\hline \multicolumn{1}{c}{ Drug } & $\begin{array}{c}\text { Before } \\
\text { implantation }\end{array}$ & 3 mo after \\
\hline Nitrates & 9 & 4 \\
NTG & 3 & 3 \\
$\beta$-Blockers & 12 & 11 \\
Ca ${ }^{++}$entry blockers & 16 & 14 \\
Phenprocoumon/Acenocoumarin & 9 & 19 \\
Aspirin & 11 & 20 \\
Dipyridamole & 7 & 21 \\
Sulfinpyrazone & 2 & 4 \\
ACF inhibitors & 3 & 4 \\
Digoxin & 3 & 3 \\
Diuretics & 6 & 3 \\
Antiarrhythmic drugs & 2 & 3 \\
\hline
\end{tabular}

NTG, Nitroglycerin.

complaints were typical and were documented by ST segment abnormalities either at rest or during exercise. Symptoms had to have been present for more than 7 days and unresponsive to maximal drug treatment without signs of recent myocardial infarction. All patients were discussed with the cardiothoracic surgeon and were considered not to be good candidates for reoperation on the basis of their coronary anatomy and the expected gain from surgery. In view of the stringent anticoagulation that had to be applied after stent implantation, all patients were screened for the presence of any bleeding disorders. For this reason patients with recent gastrointestinal bleeding, cerebrovascular accident, or other bleeding disorders did not undergo stent implantation. This report focuses on elective procedures; therefore two patients with evolving myocardial infarction and two with stent implantation in an occluded bypass at the time of the study will not be discussed. The mean age of the 20 men and four women was 63.6 years $( \pm 9.4)$. Six patients had hypertension and five had hypercholesterolemia. Diabetes mellitus was diagnosed in seven patients; three patients were insulin dependent, three were taking oral medication, and one was following a sugar-free diet. Three patients were current smokers. The average ejection fraction was $56 \%$ (range 0.26 to 0.70 ).

The average interval since the last bypass surgery was 72.8 months (range 1 to 166 ). The average number of bypass grafts was 1.4 (range 1 to 3 ). Thirty-five lesions were stented with 46 stents; the stenosis was located in the ostium in four patients, in the shaft in 21 , at the proximal anastomosis in six, and distally in five. In seven patients two stents were positioned in a telescoping manner, and in two patients three overlapping stents were implanted. In the remaining patients, one prosthesis was positioned at the stenosis. Medication given before stent implantation and at 3 months' follow-up is summarized in Table I. Nine patients were receiving anticoagulation therapy (acenocoumarin or phenprocoumon) before stent implantation and 19 at 3 months' follow-up.

Intravascular stent. The self-expanding stent consisted of 16 metal alloy filaments (outer diameter $0.08 \mathrm{~mm}$ ) that formed a geometrically stable tubular meshwork; the maximal outer diameter of the device that was attained after implantation was determined on the one hand from the radial forces generated by the device and on the other hand from the vascular elasticity of the vascular wall. ${ }^{12}$ In the unconstrained state the maximal diameter ranged from 3.5 to $6 \mathrm{~mm}$ (mean $4.2 \mathrm{~mm}$ ) with a length that varied from 15 to $30 \mathrm{~mm}$ (mean $22 \mathrm{~mm}$ ). Before implantation the stent was stretched and mounted on the tip of a $5 \mathrm{~F}$ central-hole catheter; subsequently the device was covered by a coaxial balloon that was removed during the procedure. To ascertain continuous outward compression of the vascular wall after implantation, the unconstrained diameter of the stent was chosen to exceed the measured reference diameter of the stenosed area by approximately $0.5 \mathrm{~mm}$.

The implantation procedure is described in detail elsewhere. ${ }^{13-15}$ In seven patients the stent was implanted without angioplasty, and in 27 the implantation was preceded by balloon angioplasty. In five patients balloon angioplasty was performed before and after stent implantation; in the remaining five the lesion was stented and angioplasty was subsequently performed in the stented artery ("Swiss kiss"). Catheters were introduced either via sheaths in the femoral artery by percutaneous puncture according to the Seldinger technique $(n=22)$ or by direct dissection of the brachial artery $(n=2)$. At the end of the procedure the brachial vessels were surgically closed. Femoral sheaths were left in place during the ensuing 24 hours; the next day the sheaths were removed 2 hours after heparin was discontinued; 1 hour later heparin was resumed.

Drug protocol before, during, and after implantation. The protocol for drug treatment consisted of administration of oral dipyridamole $(4 \times 75 \mathrm{mg})$, sulfinpyrazone $(4 \times 200 \mathrm{mg})$, and salicylic acid $(2 \times 500 \mathrm{mg}$ on the day before implantation and $1 \times 100 \mathrm{mg}$ thereafter), as well as nifedipine $(3 \times 20 \mathrm{mg})$, which was started before stent implantation and continued for approximately 3 months (Table II). Before balloon dilatation heparin, 10,000 IU, and dextran, $500 \mathrm{mg} / 4 \mathrm{hr}$, were given intravenously. Immediately after stent implantation 100,000 to 250,000 IU of urokinase was administered intracoronarily, followed by an additional 100,000 IU during the next 60 minutes. Intravenous heparin was continued at a minimal dosage of $24,000 \mathrm{IU} / 24 \mathrm{hr}$; the dosage was adjusted to double or triple the activated partial thromboplastin time (APTT). If the APTT exceeded 180 seconds, the infusion was interrupted for 1 hour and resumed at a dosage that was decreased by $5000 \mathrm{IU} / 24 \mathrm{hr}$. Heparin was continued but the dosage was reduced by $5000 \mathrm{IU} / 24 \mathrm{hr}$ when the APT'T was between 120 and 180 seconds. If the APTT was less than 70 seconds or twice control values, the dosage was increased by $5000 \mathrm{IU} / 24 \mathrm{hr}$ and the APTT was controlled 8 hours later. Oral acenocoumarol was started on the day of implantation; heparin infusion was continued until prothrombin time measured by thrombotest (TT) was lowered to $5 \%$ to $10 \%$ for two subsequent days and was slowly discontinued thereafter.

Baseline hemostatic parameters. Twelve hours before 
implantation, baseline coagulation status and bleeding time were evaluated in all patients. Bleeding time was determined according to the method of Hemker et al. ${ }^{16}$ Thrombocytes were counted by means of an automated whole blood platelet analyzer (Serono-Baker Diagnostics, Allentown, Pa.). APTT was determined with activated cephaloplastin reagent (Actin, Merz and Dade AG, Düdingen, Switzerland); prothrombin time (PT) was obtained by the method of Quick ${ }^{16}$ with calibrated thromboplastin reagent. ${ }^{17}$ In addition, fibrinogen levels were determined in citrate plasma by means of thrombin solution (Thrombin, Hoffmann-La Roche \& Co., Basel, Switzerland) according to the method of Clauss ${ }^{18}$; Factor $V$ levels were measured in citrate plasma by means of human thromboplastin reagent (Thromborel S, Behringwerke AG, Marburg, West Germany).

Thrombotest, consisting of ox brain thromboplastin devoid of coagulation factors, was used to adjust the dosage of oral anticoagulation therapy; it is a modified PT assay that is sensitive to reduced levels of coagulation factors II, VII, and X and the presence of protein-induced by the absence of vitamin $\mathrm{K}$ or antagonists that result from anticoagulation therapy. ${ }^{19}$ In view of the lack of standardization of PT determinations, the primary standard (World Health Organization international thromboplastin) was recently calibrated against three secondary standards among which ox brain thromboplastin (Thrombotest), the international normalized ratio that was subsequently assigned to each preparation, facilitates comparison of results obtained by each method. 20.21

According to the TT, coagulation activity was expressed as a percentage of control activity. In the presence of anemia or polycythemia, the values were corrected according to the specifications of the assay. TT measurements may seemingly be lowered during concomitant heparin administration; in our patients this effect was not compensated for by neutralization of serum samples with protamine sulfate. ${ }^{22}$ Instead TT was determined daily until heparin was gradually discontinued when TT values were within the therapeutic range.

\section{RESULTS}

Stent implantation. The angiographic results after stent implantation were evaluated by means of quantitative angiography, with an automated edge-detection technique. ${ }^{14,23-25}$ Before balloon dilatation the mean luminal diameter of the stenosed bypass was $1.5 \mathrm{~mm} \pm 0.9$ (range 0.7 to 2.9 ). The mean estimated reference bypass diameter at the stenosis (interpolated technique) was $3.4 \mathrm{~mm} \pm 1.1$ (range 1.6 to 7.0 ), and the average diameter of the angioplasty balloon was $3.2 \mathrm{~mm} \pm 0.6$ (range 2 to 4.2 ). The unconstrained diameter of the stent that was implanted after balloon dilatation was $4.1 \mathrm{~mm} \pm 0.7$ (range 3.5 to 6.0 ). All procedures were successful and without complications. The procedure allowed easy delivery of the device without misplacement and reduced the diameter of the stenosis to $<50 \%$. There were no
Table II. Drug treatment protocol

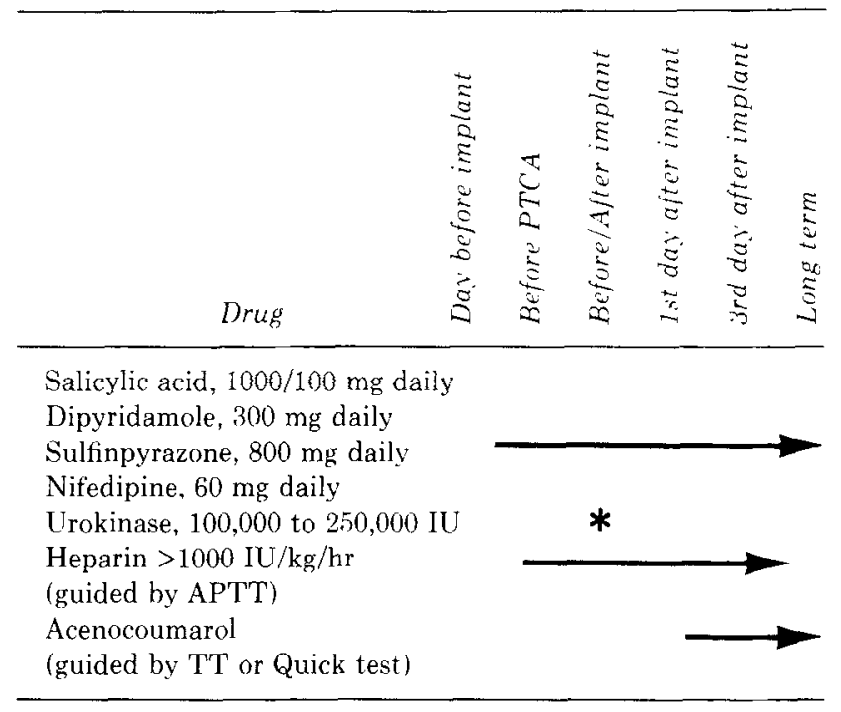

acute bypass occlusions. Immediately after angioplasty and stent implantation, the mean diameter of the lesion was $2.0( \pm 0.6)$ and $2.8( \pm 0.9) \mathrm{mm}$, respectively.

Baseline hemostatic parameters. Baseline coagulation parameters are summarized in Table III. Before stent implantation, TT, PT, and APTT were all outside the normal range, which was accounted for treatment with oral or intravenous anticoagulants in almost half of the patients (see Drug protocol before, during, and after implantation.) Fibrinogen levels were strikingly elevated as well. The changes in the coagulation parameters during and after stent implantation are shown in Fig. 1. Initially the mean APTT (closed circles, SEM as bars) increased to 120 seconds and thereafter stabilized around 80 seconds. As soon as the thrombotest values had decreased between $5 \%$ and $10 \%$ on days 2 to 3 , heparin was gradually discontinued, resulting in normalization of the APTT. Note that two patients had early occlusion of the stented graft. In patient A the occlusion (day 2) coincided with suboptimal anticoagulation treatment; in patient $B$ anticoagulants had to be discontinued on day 7 after implantation as a result of acute gastrointestinal bleeding (see below).

Complications (Table IV). Four patients had hematomas with a diameter exceeding $5 \mathrm{~cm}$, resulting in anemia that had to be corrected by blood transfusions. One patient had a transient attack, but fortunately the clinical condition normalized without sequelae. As mentioned previously patient $\mathrm{A}$, who initially had two stents implanted, had a recurrence of angina pectoris after 3 months; results of repeat angiography showed severe stenosis proximal to the 


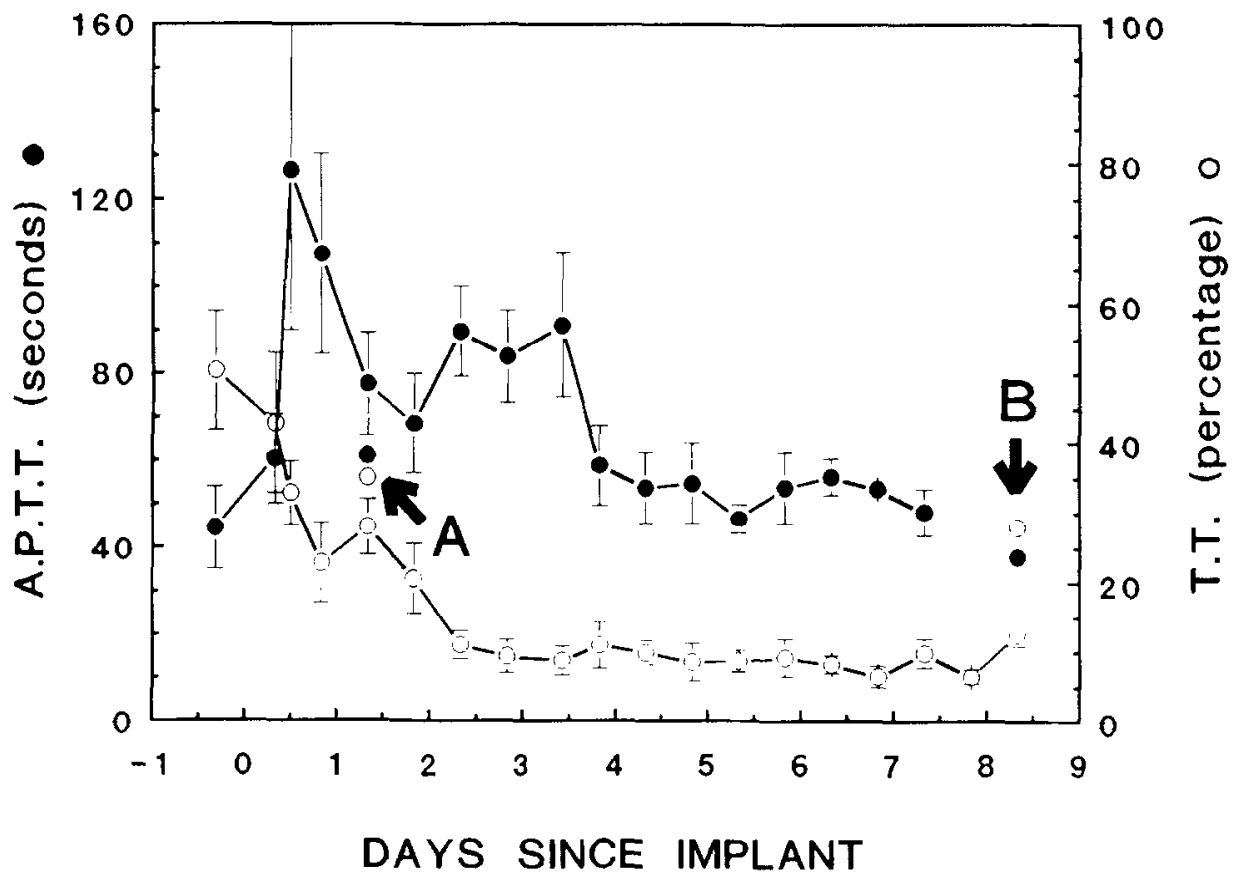

Fig. 1. Mean activated partial thromboplastin time (APTT in seconds $[\bullet])$ and thrombotest (TT in $"$, [O]) of patients before and after stent implantation (mean \pm SEM). $A$ and $B$ indicate actual APTT and $\mathrm{TT}$ in two patients at time of acute thrombotic occlusion.

Table III. Baseline coagulation status

\begin{tabular}{lc}
\hline \multicolumn{1}{c}{ Parameter } \\
\hline Bleeding time $(1-4 \mathrm{~min})$ & $2.1 \pm 0.8$ \\
Thrombocytes $\left(130-350^{*} 10 \mathrm{E}^{9} / \mathrm{L}\right)$ & $220 \pm 45$ \\
APT $(22-45 \mathrm{sec})$ & $45 \pm 37$ \\
PT $(14-19 \mathrm{sec})$ & $22 \pm 8$ \\
TT $\left(65^{\prime}\left(-150^{\prime} ;\right)\right.$ & $51 \pm 30$ \\
NT $\left(65^{\prime}-110^{\prime} ;\right)$ & $78 \pm 43$ \\
Fibrinogen $(1.6-2.8 \mathrm{gm} / \mathrm{L})$ & $3.4 \pm 0.7$ \\
Factor $\mathrm{V}(0.5-1.5 \mathrm{E} / \mathrm{ml})$ & $1.3 \pm 0.4$
\end{tabular}

APTT, activated partial thromboplastin time; NT, normotest; PT. prothrombin time; TT, thrombotest

implanted stents. This was corrected by balloon angioplasty followed by implantation of two additional stents. However, 3 days later the patient again had angina. Results of recatheterization showed that the peripheral native vessels supplied by the stented bypass graft showed thrombi that were not present on the angiogram before the second implantation. Subsequently it was decided to perform a reoperation, which was uneventful.

Patient B (Fig. 2) had upper gastrointestinal bleeding in spite of the absence of gastrointestinal complaints before the intervention. As a result of continuous vomiting with blood loss and melena, heparin and acenocoumarol were discontinued. Subsequently the patient had angina with ECG signs of myocardial ischemia (i.e., negative $T$ waves) without elevation of creatine kinase levels. During recatheterization it appeared that this was related to impending occlusion of the bypass by a fresh thrombus located outside the stented segment. Subsequently, repeat coronary bypass surgery was performed without evidence of perioperative myocardial infarction.

A third patient had an uneventful implantation of one stent. However, on day 7 he had an acute myocardial infarction (maximal creatine kinase level, 706 $\mathrm{U} / \mathrm{L}$ ) without signs of congestive heart failure. Results of recatheterization showed total occlusion of the bypass within the stent, notwithstanding adequate anticoagulation therapy. In one patient continued blood loss from the sutured brachial artery necessitated surgical reexploration; a false aneurysm of the brachial artery was sutured and the vessel reconstructed by means of a venous flap. The subsequent clinical course was uneventful, and the patient was given anticoagulants and discharged. One patient had hematuria without anemia.

\section{DISCUSSION}

Short-term follow-up after stent implantation. Our results show that stent implantation after balloon angioplasty of stenosed venous bypass grafts is technically feasible and successful at an early stage, provided that the patients are carefully selected. To be a candidate for stent implantation, each patient was 
Table IV. Complications of stent implantation

\begin{tabular}{lr}
\hline \multicolumn{1}{c}{ Complication } & $N$ \\
\hline No complications & 12 \\
Hematoma & 3 \\
$\quad$ Infected & 1 \\
Groin hematoma (intermediate) & 3 \\
Groin hematoma (excessive) & 4 \\
$\quad$ with transfusion & 1 \\
Hematuria & 1 \\
Phlebitis & 1 \\
Recurrent angina resulting from native & \\
$\quad$ coronary artery disease & 1 \\
Intrahospital myocardial infarction in native & \\
$\quad$ vessels (ejection fraction $\left.0.62^{\prime}{ }^{\prime}->0.36^{\prime}{ }^{\prime}\right)$ & 1 \\
Vascular surgery for bleeding & \\
$\quad$ cubital false aneurysm & \\
\hline
\end{tabular}

screened for the presence of all possible contraindications for anticoagulation therapy. Therefore possible bleeding disorders, notably upper or lower gastrointestinal bleeding as a result of ulcers, gastritis, esophageal varices, or Mallory-Weiss syndrome, had to be ruled out. Other disorders that precluded stent implantation were any recent bleeding, cerebral hemorrhage, severe liver or kidney dysfunction, thrombocyte dysfunction, thrombocytopenia, or hypertension (>180/110 $\mathrm{mm} \mathrm{Hg}$ ), and diabetic or hypertensive retinopathy. For this reason complete hematologic and coagulation status was obtained from all patients before the intervention, and stool samples were checked for the presence of microscopic blood loss. Notwithstanding these precautions, one patient had upper gastrointestinal bleeding, necessitating interruption of the anticoagulation therapy.

Another important determinant of the ultimate success is the regional anatomy of the coronary arteries that are supplied by the diseased venous bypass graft. In our previous experience with stenting of coronary arteries, poor distal runoff, small diameter of the stenosed vessel, and previous myocardial infarction in the region supplied by the stenosed artery, as well as haziness of the dilated lesion, were contraindications for stent implantation. Our favorable results within the first day may be explained, at least in part, by the diameter of the venous grafts, which exceeded the luminal diameter of native coronary vessels by a factor of 1.5 to 3 .

In general the extensive anticoagulation therapy was continued until 3 months after stent implantation. The rationale for this approach is based on observations in animal experiments; it has been reported that stents that were implanted in pig femoral arteries were completely covered by endothelium within 1 to 3 weeks. ${ }^{26}$ Since histologic data in humans

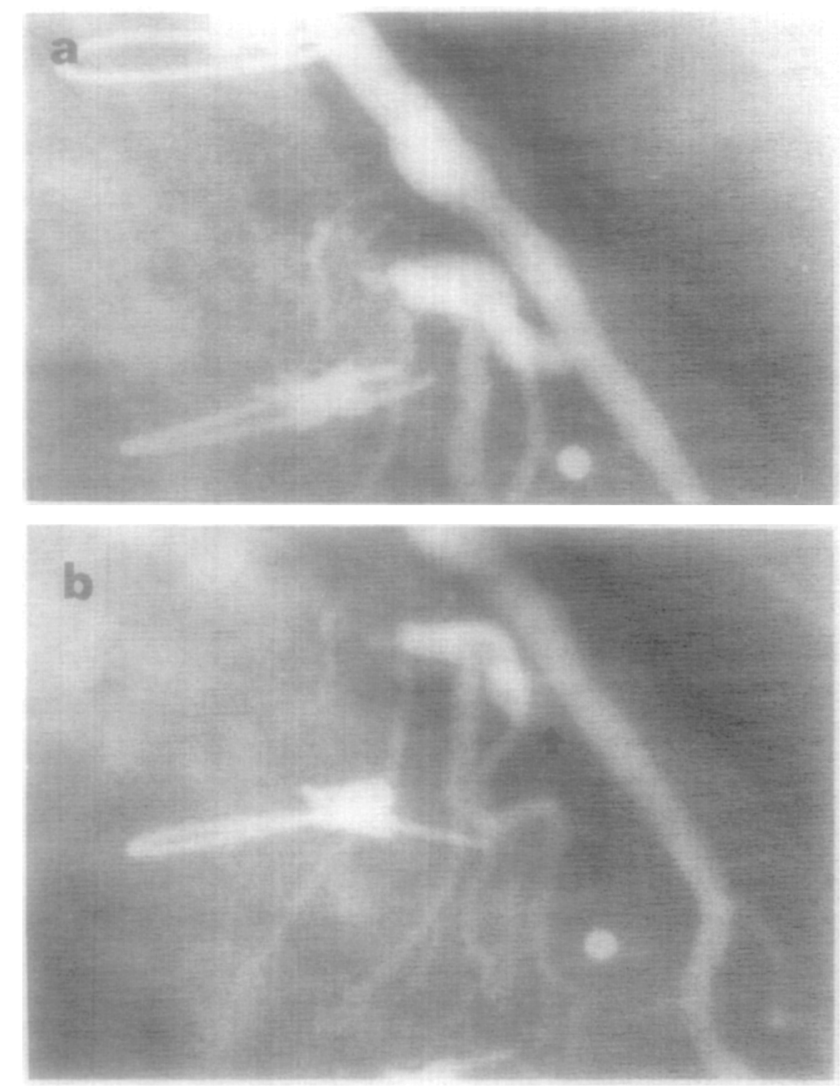

Fig. 2. Coronary angiogram (patient B) of venous bypass graft connected to left anterior descending coronary artery, immediately after successful stent implantation (a) and during acute occlusion (b), showing impending occlusion of bypass graft by fresh thrombus located outside stented segment (arrow).

are still lacking, we decided not to risk acute thrombotic occlusion and therefore continued anticoagulation therapy until 3 months after implantation. Stringent anticoagulation was accomplished by scrupulous and frequent monitoring of the coagulation status of each patient for approximately 3 months. It is conceivable that in some patients the burden of frequent visits to the outpatient clinic and extensive medication may compromise the quality of life to such an extent that it would have been preferable to perform bypass surgery despite the possibility of increased risk of myocardial infarction or even death as a result of the latter procedure. The possible advantageous long-term effects of stent implantation on the rate of restenosis should be well established to gain acceptance as an alternative to bypass surgery. Thus long-term follow-up including quantitative angiography of treated patients is necessary and is currently under investigation.

Hemostatic monitoring: Theoretic and practical considerations. The adequacy of anticoagulation therapy 
was controlled by assessing the TT (in percentages) and APTT levels (in seconds). The concept of the thrombotest was initially introduced by Owren. ${ }^{19}$ It is well known that coumarin derivatives, such as acenocoumarol or phenprocoumon, prevent incorporation of vitamin $\mathrm{K}$ in coagulation factors II, VII, IX, and $\mathrm{X}$. Consequently inactive proteins induced by the absence of vitamin $\mathrm{K}$ (or antagonists) are formed. ${ }^{16}$ The resulting lengthening of coagulation time may be measured by means of the thrombotest; the test assesses the serum coagulation time in the presence of excess kefaline, thrombokinase, factors $\mathrm{V}$ and VIII, and calcium chloride. The assay is sensitive to the presence of coagulation factors II, VII, (IX), and $\mathrm{X}$ and is more or less equivalent to the PT as measured by the Quick test. Normal thrombotest values of 40 seconds or less have been reported in healthy control subjects; in our patients the preferable TT level ranged between 180 and 210 seconds, which is equivalent to a thrombotest value of $5 \%$ to $10 \%$ (international normalized ratio 2.5 to 5 ). According to the manufacturer, thrombotest values may be seemingly increased in the presence of heparin. ${ }^{22}$ Although this does not seem relevant in daily clinical practice, this effect may be compensated for by neutralization of the serum before the test. We preferred to gradually discontinue heparin administration and frequently monitored TT at the same time.

The effect of heparin administration was adjusted according to the APTT. The patient's pretreatment APTT ( 30 to 35 seconds) was increased by a factor of 2 or 3 . The white cell count appeared elevated after the procedure in almost every patient; this may have been caused by acenocoumarol, which may induce redistribution of white cells, notably neutrophils, as has been reported recently. ${ }^{27}$ However, in our patients the observed leukocytosis may be equally well accounted for by hematoma formation and subsequent resorption.

We conclude that stent implantation after percutaneous transluminal coronary angioplasty of stenosed venous bypass grafts may result in normalization of the regional hemodynamic profile. Unfortunately the drastic improvement in rheologic conditions, as evidenced by the virtual disappearance of poisseuille resistance and normalization of laminar flow, ${ }^{14}$ was inadequate to prevent thrombotic complications in three patients. Our observations therefore suggest that the primary cause of thrombotic occlusion must be ascribed to the thrombogenic nature of the stent itself or to its direct thrombogenic interaction with the diseased and atherosclerotic vessel wall. Likewise the observed thrombotic com- plications may have resulted from local thrombogenic mechanisms that were triggered by the interaction of the self-expanding stent with the more compliant vessel wall. To prevent these acute thrombotic complications, we applied stringent anticoagulation therapy after successful implantation of the stent. The rationale for the drug treatment was to provide maximal antithrombotic effects by interference with the normal function of platelets and endothelial lining and by inhibition of coagulation factors.

As a result of stent implantation the intimal lining of the venous graft was damaged, which may have given rise to aggregation of platelets and formation of thrombin. ${ }^{28}$ Therefore platelet aggregation was antagonized by aspirin and sulfinpyrazone, both of which inhibit production of thromboxane $\mathrm{A}_{2}{ }^{29.30}$; dipyridamole, on the other hand, was administered in an attempt to inhibit platelet deposition and aggregation to damaged vessels because of increased production of platelet c-AMP. ${ }^{31,32}$ Thrombin formation was prevented by administration of heparin and if present lysed by urokinase, thereby preventing acute occlusion. ${ }^{33,34}$ Vasospasm, which may be triggered by release of vasoactive agents during angioplasty, was prevented by nifedipine and diltiazem. ${ }^{35}$ Dextran (Rheomacrodex) was infused, since this inert plasma volume expander is known to reduce platelet adhesiveness and platelet aggregation induced by injury to the vessel wall. ${ }^{36,37}$ In addition, it reduces factor VIII activity ${ }^{38}$ and increases clot lysability. ${ }^{39}$ It remains to be seen whether this extensive anticoagulation regimen is an absolute requirement for prevention of the complications of acute thrombosis. A less extensive protocol may appear equally effective for prevention of early thrombotic complications after stent implantation in venous bypass grafts. ${ }^{40}$ In addition, the number of patients with complications induced by the stringent anticoagulation regimen may be reduced.

The stents that were implanted in our patients were not coated. It has been reported that heparinor polymer-coated stents may be advantageous, since endothelial cell proliferation is enhanced by various anticoagulation and antiplatelet drugs, as was shown in cell cultures. Notably low-molecular-weight heparin seems to exert a favorable effect on endothelial cell growth. ${ }^{41}$ Future designs for stents should include polished endings for the wires that form the device; alternatively the device could be covered by a layer of endothelial cells or polymer or corticoid coating to prevent early thrombotic occlusion and endothelial proliferation for the longer term..$^{42}$ More recently it has been suggested that the device be cov- 
ered with heparin benzalkonium chloride complex (H-BAC), which is known to prevent thrombosis. Other designs such as biodegradable devices, may also prove useful and diminish the rate of restenosis.

To prevent some of the bleeding complications, anticoagulation therapy, notably acenocoumarin, may be considered 1 day before stent implantation. Likewise removal of the arterial sheaths immediately after the procedure rather than 12 hours later could reduce the number of severe hematomas.

Recently it was suggested that the effects of heparin administration be monitored by measurement of activated clotting time during and after percutaneous transluminal angioplasty. ${ }^{43}$ The same technique could be applied equally well in patients after stent implantation. Since the method is reliable, cheap, and easy to perform, it may be considered more frequently to adjust heparin administration and attain an optimal coagulation status. Introduction and application of these and other laboratory techniques without any doubt will reduce the risk of thrombotic occlusions resulting from inadequate heparin administration.

\section{REFERENCES}

1. Shelton ME, Forman MB, Virmani R, Bajaj A, Stoney WS, Atkinson JB. A comparison of morphologic and angographic findings in long-term internal mammary artery and saphenous vein bypass grafts. J Am Coll Cardiol 1988;11:297-307.

2. Loop FD, Lytle BW, Cosgrove DM, Stewart RW, Goormasti M, Williams GW, Golding LAR, Gill CC, Taylor PC, Sheldon WC, Proudfit WL. Influence of the internal mammary artery graft on 10-year survival and other cardiac events. N Engl J Med 1986;314:1-6.

3. Cameron MD, Kemp HG, Green GE. Bypass surgery with the internal mammary artery graft: 15 -year follow-up. Circulation 1986;74 (suppl III):III30-6.

4. de Feyter PJ, Serruys P, van den Brand M, Meester H, Beatt $K$, Suryapranata $H$. Percutaneous transluminal angioplasty of a totally occluded venous bypass graft: a challenge that should be resisted. Am .J Cardiol 1989;64:88-90.

5. Grüntzig AR, Senning A, Siegenthaler WE. Nonoperative dilatation of coronary-artery stenosis. Percutaneous transluminal coronary angioplasty. N Engl J Med 1979;301:61-8.

6. Meester BJ, Samson M, Suryapranata $H$, Bonsel G, van den Brand M, de Feyter PJ, Serruys PW. Long-term follow-up after attempted angioplasty of saphenous vein grafts: the Thoraxcenter experience 1981-1988. Eur Heart J 1991;12 (In press)

7. Saber RS, Edwards WD, Holmes DR, Vlietstra BR, Reeder GS. Balloon angioplasty of aortocoronary saphenous vein bypass grafts: a histopathologic study of six grafts from five patients, with emphasis on restenosis and embolic complications. J Am Coll Cardiol 1988;12:1501-9.

8. Serruys PW, Rensing BJ, Luijten HE, Hermans WRM, Beatt KJ. Restenosis after coronary angioplasty. In: Meier B, ed. Interventional cardiology. Toronto: Hogrefe \& Huber Publishers, 1990:79-116.

9. Ernst SMPG, van den Feltz TA, Bal ET, van Bogerijen L, van den Berg E, Ascoop CAPL, Plokker HWT. Long-term angiographic follow-up, cardiac events, and survival in patients undergoing percutaneous transluminal coronary angioplasty. $\mathrm{Br}$ Heart J 1987;57:220-5.
10. Urban P, Sigwart U, Golf S, Kaufmann U, Sadeghi H, Kappenberger L. Intravascular stenting for stenosis of aortocoronary venous bypass grafts. J Am Coll Cardiol 1989;13:108591.

11. Sigwart U, Puel J, Mirkovitch V, Joffre F, Kappenberger L. Intravascular stents to prevent occlusion and restenosis after transluminal angioplasty. N Engl J Med 1987;316:701-6.

12. Ellis SG, Topol E. Intracoronary stents: will they fulfill their promise as an adjunct to angioplasty? J Am Coll Cardiol 1989;13:1425-30.

13. Puel J, Juilliere Y, Betrand ME, Rickards AF, Sigwart U, Serruys $\mathrm{PW}$. Early and late assessment of stenosis geometry after coronary arterial stenting. Am J Cardiol 1988;61:546-53.

14. Serruys PW, Juilliere $\mathrm{Y}$, Bertrand ME, Puel J, Rickards AF, Sigwart U. Additional improvement of stenosis geometry in human coronary arteries by stenting after balloon dilatation. Am J Cardiol 1988;61:71G-6G.

15. Serruys PW. Stenting of peripheral and coronary arteries with an endoprosthesis following balloon angioplasty (in Dutch). Ned Tijdschr Cardiol 1988;2:5-17.

16. Hemker HC, Loeliger EA, Veltkamp JJ (eds). Human blood coagulation. Biochemistry, clinical investigation and therapy. Boerhaave series. Leiden: Leiden University Press, 1969.

17. Quick AJ. Thromboplastin as a reagent. Thromb Diathes Haemorrh (Stuttgart) 1970;23:585-92.

18. Clauss A. Gerinnungsphysiologische Schnellmethode zur Bestimmung des Fibrinogens. Acta Haematol 1957;237:17.

19. Owren PA. Thrombotest; a new method for controlling anticoagulant therapy. Lancet 1959;2:754-8.

20. Hermans J, van den Besselaar K, Loeliger EA, van der Velde EA. A collaborative calibration study of reference materials for thromboplastins. Thromb Haemost 1983;50:712-17.

21. Hirsh J, Deykin D, Poller L. "Therapeutic range" for oral anticoagulant therapy. Chest 1986;89:11S-15S.

22. Nyman D, Wahlberg P. A rapid procedure for laboratory control of simultaneous treatment with intravenous heparin and oral anticoagulant. Acta Med Scand 1972;192:125-8.

23. Reiber JHC, Serruys PW, Slager CJ. Quantitative coronary and left ventricular cineangiography. Methodology and clinical applications. Dordrecht: Martinus Nijhoff Publishers, 1986.

24. Reiber JHC, Serruys PW, Kooijman CJ, Wijns W, Slager CJ, Gerbrands JJ, Schuurbiers JCH, den Boer A, Hugenholtz PG. Assessment of short-, medium-, and long-term variations in arterial dimensions from computer-assisted quantitation of coronary cineangiograms. Circulation 1985;71:280-8.

25. Serruys PW, Reiber JHC, Wijns W, van den Brand M, Kooijman CJ, ten Katen $\mathrm{HJ}$, Hugenholtz PG. Assessment of perculaneous transluminal coronary angioplasty by quantitative coronary angiography: diameter versus densitometric area measurements. Am J Cardiol 1984;54:482-8.

26. van der Giessen WJ, Serruys PW, Visser WJ, Verdouw PD, van Schalkwijk WP, Jongkind JF. Endothelialization of intravascular stents. J Intervent Cardiol 1988;1:109-20.

27. Herrmann A, Kreuzer ' 2 . Beobachtung einer Acenocoumarol induzierten Granulocytose. Klin Wochenschr 1988;66:639-42.

28. Vanhoutte PM, Houston DS. Platelets, endothelium and vasospasm. Circulation 1985;72:728-34.

29. Fuster V, Adams PC, Badimon JJ, Chesebro JH. Platelet-inhibitor drugs' role in coronary artery disease. Progr Cardiovasc Dis $1987 ; 29: 325-46$

30. Harker LA, Fuster V. Pharmacology of platelet inhibitors. J Am Coll Cardiol 1986;8:21B-32B.

31. McBride W, Lange RA, Hillis LD. Restenosis after successful coronary angioplasty. N Engl J Med 1988;318:1734-7.

32. Schwartz L, Bourassa MG, Lespérance J, Aldridge HE, Kazim F, Salvatori VA, Henderson M, Bonan R, David PR. Aspirin and dipyridamole in the prevention of restenosis after percutaneous transluminal coronary angioplasty. N Engl J Med 1988;318:1714-19.

33. Wessler S, Gitel SN. Pharmacology of heparin and warfarin. J Am Coll Cardiol 1986;8:10R-20B 
34. European Collaborative Study. Controlled trial of urokinase in myocardial infarction. Lancet 1975;2:624-6.

35. Wilson RF, Laxson DD, Lesser JR, White CW. Intense microvascular constriction after angioplasty of acute thrombotic coronary arterial lesions. Lancet 1989;1:807-11.

36. Cronberg S, Robertson B, Nilsson IM, Nilehn JE. Suppressive effect of dextran on platelet adhesiveness. Thromb Diath Haemorrh 1966;16:384-94.

37. Arfors KE, Hint HC, Dhall DP, Matheson NA. Counteraction of platelet activity at sites of laser induced endothelial trauma. Br Med J 1968;4:430-1.

38. Aberg M, Hedner U, Bergentz BE. Effect of dextran on factor VIII (antihemophilic factor) and platelet function. Ann Surg 1979;189:243.

39. Aberg M, Bergentz SE, Hedner U. The effect of dextran on the lysability of ex vivo thrombi. Ann Surg 1975;181:342-5.
40. Schatz RA, Leon M, Baim D, Ellis S, Marco J, Erbel R, Goldberg $\mathrm{S}$. Short-term clinical results and complications with the Palmaz-Schatz coronary stent [Abstract]. J Am Coll Cardiol 1990; 15:117A.

41. Lindblad B, Wright SW, Burkel WE, Wakefield TW, Graham LM, Sell R, Stanley JC. Endothelial cell proliferation in vitro after incubation with anticoagulant and antiplatelet drugs. Artery $1988 ; 16: 15-24$.

42. Dichek DA, Neville RF, Zwiebel JA, Freeman SM, Leon MB, Anderson WF. Seeding of intravascular stents with genetically engineered endothelial cells. Circulation 1989;80:1347-53.

43. Rath B, Bennett DH. Monitoring the effect of heparin by measurement of activated clotting time during and after percutaneous transluminal coronary angioplasty. Br Heart $\mathrm{J}$ 1990;63:18-21.

\section{BOUND VOLUMES AVAILABLE TO SUBSCRIBERS}

Bound volumes of the AMERICAN HEART JOURNAL are available to subscribers (only) for the 1991 issues from the Publisher at a cost of $\$ 51.00$ for domestic, $\$ 72.57$ for Canadian, and $\$ 69.00$ for international subscribers for Vol. 121 (January-June) and Vol. 122 (July-December). Shipping charges are included. Each bound volume contains a subject and author index and all advertising is removed. Copies are shipped within 60 days after publication of the last issuc in the volume. The binding is durable buckram with the journal name, volume number, and year stamped in gold on the spine. Payment must accompany all arders. Con tact Mosby-Year Book, Inc., Subscription Services, 11830 Westline Industrial Drive, St. Louis, Missouri 63146, USA; phone (800) $325-4177$, ext. 4351

Subscriptions must be in force to qualify. Bound volumes are not available in place of a regular Journal subscription. 